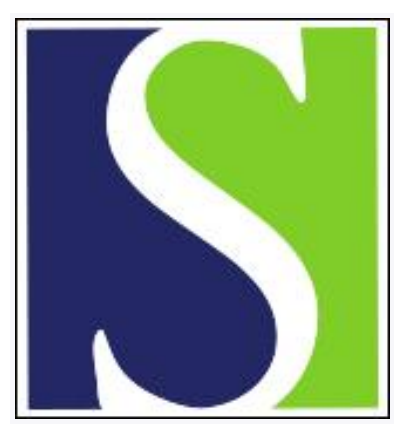

Scand J Work Environ Health 1981;7(1):18-30

https://doi.org/10.5271/sjweh.2572

Issue date: Mar 1981

Felling work, low-back pain and osteoarthritis.

by Sairanen E, Brüshaber L, Kaskinen M

Key terms: back; back symptom; disc degeneration; felling work; low back; low-back pain; osteoarthritis; pain

This article in PubMed: www.ncbi.nlm.nih.gov/pubmed/6458885

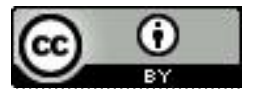




\title{
Felling work, low-back pain and osteoarthritis
}

\author{
by Eero Sairanen MD, ${ }^{1}$ Leena Brüshaber, ${ }^{2}$ Matti Kaskinen, $\mathrm{MD}^{3}$
}

\begin{abstract}
SAIRANEN E, BRÚSHABER L, KASKINEN M. Felling work, low-back pain and osteoarthritis. Scand $j$ work environ health 7 (1981) 18-30. Low-back pain and the occurrence of osteoarthritis were investigated among 226 lumberjacks employed in felling work for an average of 20 a. The reference group comprised 98 persons involved in either light physical work or office activities. There were no statistically significant differences between the two groups with regard to the occurrence of low-back pain and the subjective degree of low-back pain. According to the radiographic findings the lumberjacks had statistically more occurrences $(62 \%)$ of disc degeneration than the referents $(50 \%)$. No association between length of exposure to felling work and the prevalence of lumbar disc degeneration could be established. The occurrence of osteoarthritis in the hip and knee joints of the lumberjacks was 5 and $3 \%$ for the lumberjacks and the referents, respectively.
\end{abstract}

Key terms: back symptom, disc degeneration.

Disorders of the musculoskeletal system are very common, and their incapacitating effects on work ability, especially with respect to the back, have significantly increased in Scandinavia during the last few decades (53). It appears that lowback pain is the most expensive disease among the 30 - to $60-\mathrm{a}$ age group of the working population in most industrialized countries (43). For this reason more and more attention is being given to the investigation of these disorders and, in particular, their possible occupational origins. Investigations have also been conducted on this issue in Finland (27, 66, 67 ), and through them many problems have been exposed which are specific to the investigation of the occurrence of musculoskeletal disorders, their assessment, and etiology $(59,65)$.

1 University of Turku, Turku, Finland (retired).

2 Enso-Gutzeit Ltd, Imatra, Finland.

3 Department of Radiology, Rauha Hospital, Rauha, Finland.

Reprint requests to: Dr Eero Sairanen, Tyysterranta 14, SF-53900 Lappeenranta 90, Finland.
Forest felling work is still considered to be one of the most physically demanding occupations, even though technical improvements and mechanization have helped to make it less strenuous than before. Investigations $(18,21,26,28,48,64)$ of the musculoskeletal disorders of forest workers have shown that from 38 to $82 \%$ of the workers have back ailments. The present study, which employed a crosssectional study design, deals with the effect of felling work on low-back pain and osteoarthritis in hip and knee joints.

In this respect a brief description, based on personal observations and material available from Risto Ojalainen (personal communication), of felling work in Finnish forests is necessary.

Felling work in Finland is done on contract or as piecework, and the work is done under all kinds of weather conditions. The dynamic and static parts of the work, the duration of stress, and the magnitude of peak stresses all vary greatly.

The company for which the subjects of this study worked had instructed its workers in ergonomically proper work methods since the start of the 1970s. The 
weight of single loads to be lifted range from a few kilograms up to $90 \mathrm{~kg}$. Power saws are used $60-70 \%$ of the time. Workers use muscular static force to carry and support their saws. Since the $1950 \mathrm{~s}$ the weight of the saw has dropped from 16 $\mathrm{kg}$ to $6-7 \mathrm{~kg}$.

The Finnish landscape is uneven and rocky, and the forests are full of underbrush. There are many steep slopes, and during the winter the snowfall is considerable and conditions are slippery. All of these environmental factors increase the work strain and the risk of accident. The work posture is stooped $50-60 \%$ of the time, particularly during the trimming, measuring, sectioning and felling of trees. The breakdown of the effective working time is as follows:

\section{felling}

trimming

measuring and sectioning

collecting of logs

transferring (manual)

$$
\begin{aligned}
10-20 & \% \\
15-50 & \% \\
5-15 & \% \\
5-50 & \% \\
5-15 & \%
\end{aligned}
$$

Every hour or so a mandatory 5- to 10min break to fill the gas tank of the saw interrupts the work rhythm. The daily work period is usually $5-8 \mathrm{~h}$, including a lunch break, and the work week is $5 \mathrm{~d}$ long.

\section{Subjects and methods}

The lumberjacks in this study totalled 226 ; they came from middle and eastern Finland. The criterion for selection was that they had been doing felling work for at least 10 a, seven to eight months of the year. Their ages ranged from $26-65$ a, the average being 42 a. The length of employment in felling work was, on the average, 20 a. All were employed by Enso-Gutzeit Ltd. During the 1970s the total number of lumberjacks in the concern usually exceeded 1,000 .

Between 1970 and 1977 a total of 470 lumberjacks left the company, 28 retired, 18 died, and 79 retired because of incapacity to work. Of the latter 79, 29 retired because of back ailments.

The different types of work were grouped into the following four classes on the basis of the amount of stress apt to be placed on the lower back (3): class I: administrative work in which employees sit at desks; ie, white-collar workers; class II: clerical and/or light physical work such as that of stockroom clerks, light bench assembly, first line supervisors, salesmen (occasional light lifting, considerable walking, some bending, stooping, squatting); class III: moderate physical activity, such as for indoor craftsman and in many factory jobs (occasional lifting of objects weighing over $25 \mathrm{~kg}$, frequent lifting of $5-15 \mathrm{~kg}$ ); class IV: heavy physical stress on the back, eg, the work of outdoor craftsmen, construction laborers, foundrymen, etc (frequent heavy lifting (over $25 \mathrm{~kg}$ ) - often combined with bending, twisting, working above ground or on irregular surfaces). Lumberjacks belong to class IV, which is the most physically strenuous on the back.

The referents comprised 98 persons from an office and a cellulose and board mill of the same company. Over half were involved in office work, and the rest were either repairmen or electricians. The majority of the referents belonged to the first and second back strain classes, and only a small percentage to the third. The age range was approximately the same as for the subjects, $22-64 \mathrm{a}$, and the average was 42 a.

Both the lumberjacks and the referents were selected according to occupation from the company's roll of employees, and they were asked to attend a medical examination. Two of the selected lumberjacks and four of the referents did not participate.

The group formed to conduct the examination comprised two physicians (a rheumatologist and a radiologist), a physical therapist, and a research assistant. The examinations were conducted in the following localities: Iisalmi, Joensuu, Ilomantsi, Savonlinna, Imatra, Mikkeli, and Jyväskylä.

The examination for each lumberjack and referent included the following:

1. Both a physician and the physical therapist conducted a separate interview with each lumberjack and referent.

2. One of the physicians conducted a general check-up of, among other things, the prostate gland, the pulse and skin 
sensitivity of the legs, patella and Achilles tendon reflexes, and Lasègue test performances.

3. One physician examined the back $(6$, 34 ) with the exception of the back's movement and posture, which the physical therapist evaluated. The movements of the back were determined as follows: flexion: a normal rating was applied when the finger tips came midway down the tibia, and a test was also performed according to Schober (58); extension: visually determined, the normal rating being about $30^{\circ}$ backward; lateral bending: considered normal if the fingers extended below the knee; scoliosis, lordosis and kyphosis: visually determined.

4. The physical therapist tested the straight abdominal muscles and support muscles of the back with manual testing (12). A separate control for the muscle test was made at the University of Jyväskylä; it involved dynamometer measurements of 12 fellers (68). The results of the manual tests and those from the dynamometer were similar. In addition a physical therapist measured the length of the lower limbs.

5. Radiographs were taken at the local health center, hospital or in the company's $\mathrm{X}$-ray department. The lumbar spine (anteroposterior and lateral pictures while

Table 1. Occurrence $(\%)$ of low-back pain.

\begin{tabular}{lcc}
\hline & $\begin{array}{c}\text { Lumberjacks } \\
(\mathrm{N}=226)\end{array}$ & $\begin{array}{c}\text { Referents } \\
(\mathrm{N}=98)\end{array}$ \\
\cline { 2 - 3 } No pain & 38 & 40 \\
Occasional pain & 58 & 56 \\
Constant pain & 4 & 2 \\
\hline
\end{tabular}

Table 2. Occurrence $(\%)$ of subjective degree of low-back pain.

\begin{tabular}{ccc}
\hline Degree a & $\begin{array}{c}\text { Lumberjacks } \\
(\mathrm{N}=141)\end{array}$ & $\begin{array}{c}\text { Referents } \\
(\mathrm{N}=58)\end{array}$ \\
\hline 0 & 40 & 41 \\
I & 41 & 34 \\
II & 19 & 25 \\
\hline
\end{tabular}

a The following scale was used: $0=$ not disturbing; I = mildly affects work ability, occasionally absent from work; II = seriously affects work ability, often absent from work. lying down), sacroiliac and hip joints (anteroposterior), and knees (anteroposterior and lateral pictures) were X-rayed. Each person's radiographs were first evaluated by the radiologist, and then by the rheumatologist and the radiologist together. The disagreements between the two evaluations were few and insignificant. Any signs of disc degeneration were categorized into one of the four following grades (32): grade 1: slight anterior wear and osteophyte formation; grade 2: definite anterior wear and osteophyte formation; grade 3: osteophyte formation and disc narrowing; grade 4: large osteophytes, marked disc narrowing, sclerosis of vertebral plates, and posterior subluxation.

6. One physician examined the hip and knee joints with the physical therapist.

\section{Statistical methods}

The t-test was used to check the percentages and differences between the means. In some cases the chi-square test was also used to test the differences between the means.

To eliminate the confounding effect of age on the studied relationship between duration of felling work (exposure variable) and degree of disc degeneration (outcome variable), three main approaches were employed, a partial correlation and regression analysis (10), an analysis of covariance via multiple regression (10), and an extended chi-square test procedure for age-stratified two-way (exposureoutcome) frequency tables (37). Computation of the Kolmogorov-Smirnov test was used to detect differences in the age distribution on recruitment to lumber work between radiographically diagnosed subgroups of workers with and without certain signs or illness.

\section{Results}

\section{Interview}

The previous occurrence of low-back pain lasting for at least $3 \mathrm{~d}$, as reported in the interview, is presented in table 1 . There were no significant differences between the groups in regard to this factor $\left(\chi^{2}=\right.$ 
1.24). There were 70 cases $(31 \%)$ of lowback pain associated with trauma determined anamnestically and only 5 cases $(18 \%)$ among the referents.

The subjective degree of previous back pain is shown in table 2. There were no significant differences between the lumberjacks and referents in regard to the subjective degree of low-back pain $\left(\chi^{2}=\right.$ 0.99 ). The subjective work ability of the lumberjacks had remained better than that of the referents $(p<0.05)$.

The lumberjacks were asked when they first experienced low-back pain (fig 1). This information was received from only 123 persons because not all could recall the first instance of pain. Often the pains began at a young age, on the average, 34 a $(18-57$ a).

Fifty-five of the referents remembered at what age they first experienced lowback pain. The average age when the pains started was 32 a (range $13-57$ a) There was no statistically significant difference $\left(\chi^{2}=2.00\right)$ between the subjects and the referents as to when the low-back pain began.

An inquiry was also made of the number of years in forest work before the beginning of low-back pain. Six of the lumberjacks had had back pain before they entered forest work. The remaining 117 are described in fig 2. More than one-half of the remaining 117 had low-back pain within the first 10 a of forest work, and one-fourth had it already after $5 \mathrm{a}$. The average length of time before low-back pain occurred was 12 a.

There were 85 lumberjacks who had not experienced low-back pain (fig 3). The average length of employment in forest work for these men was 19 a.

The length of absence from work during the last year is presented in table 3. The fellers had longer absences from work than the referents $(p<0.05)$.

Some of the symptoms of previous back pain are shown in table 4 . The most common symptoms of the lumberjacks were a stiff back and an aching back. The referents reported tiredness of the back and soreness of movement. The lumberjacks had relatively more symptoms than the referents.

The subjects were asked about the measures taken to relieve low-back pain

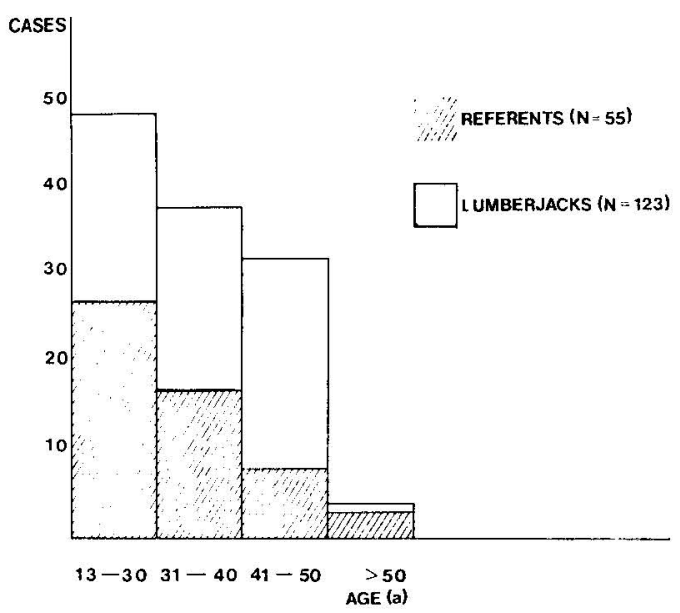

Fig 1. Age when low-back pain was first experienced.

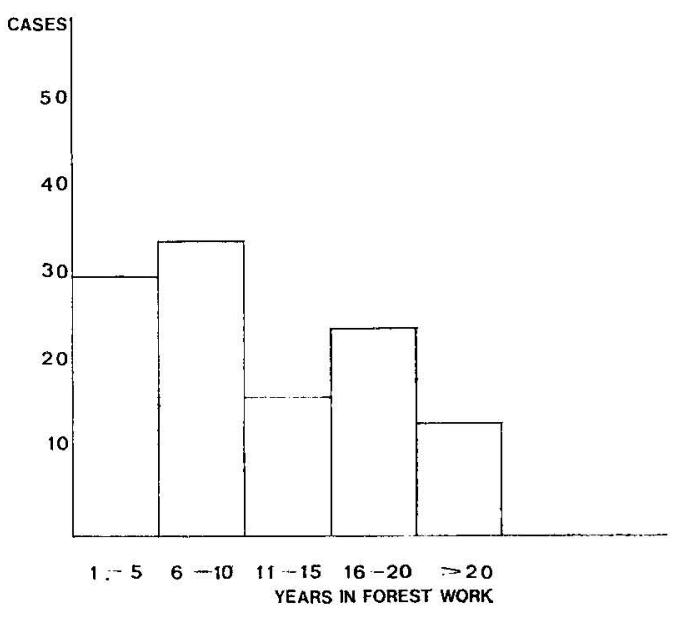

Fig 2. Number of years in forest work before the occurrence of low-back pain $(\mathrm{N}=117)$.

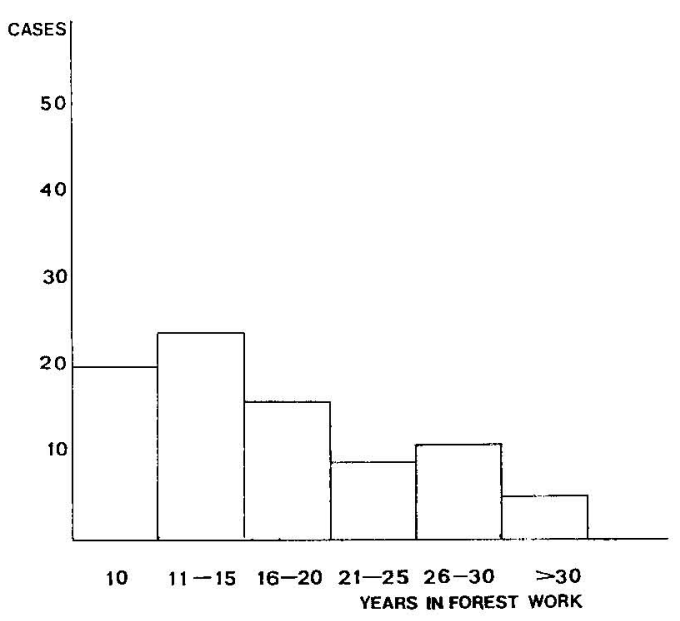

Fig 3. Number of years in forest work for lumberjacks without low-back pain $(N=85)$. 
(table 5). Physical therapy was more common among the referents than the lumberjacks $(p<0.001)$. It appeared that local circumstances were significant in this respect, as medical services were more easily accessible from the workplace of the referents than from that of the lumberjacks. There was no significant difference $(t=1.13)$ between the two groups' use of medicines nor between their number of visits to a physician. More lumberjacks were admitted to hospital care, but the difference was not significant.

\section{General check-up}

The state of health of the lumberjacks and referents was generally satisfactory

Table 3. Absenteeism ( $\%$ ) from work because of low-back pain during the past year.

\begin{tabular}{ccccc}
\hline & $1-7 \mathrm{~d}$ & $8-14 \mathrm{~d}$ & $15-29 \mathrm{~d}$ & $\geq 30 \mathrm{~d}$ \\
\cline { 2 - 5 } & & & & \\
$\begin{array}{c}\text { Lumberjacks } \\
(\mathrm{N}=226)\end{array}$ & 8 & 2 & 2 & 8 \\
$\begin{array}{c}\mathrm{R}=2 \mathrm{Nents} \\
(\mathrm{N}=98)\end{array}$ & 5 & 3 & 0 & 0 \\
\hline
\end{tabular}

Table 4. Number of indviduals with certain lowback pain symptoms.

\begin{tabular}{lcc}
\hline Symptom & Lumberjacks & Referents \\
\hline Daytime ache & 81 & 15 \\
Nighttime ache & 40 & 8 \\
Stiffness & 70 & 17 \\
Tenderness of move- & 51 & 21 \\
ment at work & 38 & 24 \\
Back fatigue & & 2 \\
Pain extending down & 9 & \\
the leg &
\end{tabular}

Table 5. Frequency $(\%)$ of measures taken to relieve low-back pain.

\begin{tabular}{lcc}
\hline Measure & $\begin{array}{c}\text { Lumberjacks } \\
(\mathrm{N}=141)\end{array}$ & $\begin{array}{c}\text { Referents } \\
(\mathrm{N}=58)\end{array}$ \\
\hline $\begin{array}{l}\text { Occasional use of } \\
\text { analgesic }\end{array}$ & 28 & 36 \\
Constant use of & 3 & 0 \\
analgesic & 11 & 36 \\
Physical therapy & 60 & 59 \\
Visits to physician & 9 & 3 \\
Hospital care & & \\
\hline
\end{tabular}

or good. Forty-three persons had enlarged prostates, and 13 had tender ones. Pulsations in the legs proved to be normal. One person had no patellar reflex, and eight had a positive Lasègue's test. There was no definite disturbance in the sensory nerves of the legs.

\section{Low-back examination}

The low-back examination revealed a rather considerable amount of postural changes (table 6). The lumberjacks had more instances of scoliosis than the referents $(p<$ 0.01).

There were no significant differences between the lumberjacks and the referents with respect to restricted back movements

Table 6. Occurrence $(\%)$ of specific postures.

\begin{tabular}{lcc}
\hline Posture & $\begin{array}{c}\text { Lumberjacks } \\
(\mathrm{N}=226)\end{array}$ & $\begin{array}{c}\text { Referents } \\
(\mathrm{N}=98)\end{array}$ \\
\hline $\begin{array}{l}\text { Thoracal kyphosis } \\
\text { Diminished lumbar }\end{array}$ & 26 & 24 \\
lordosis & 17 & 16 \\
Scoliosis & 38 & 22 \\
\hline
\end{tabular}

Table 7. Prevalence $(\%)$ of restricted back movements and tenderness of movement.

\begin{tabular}{lcc}
\hline & $\begin{array}{c}\text { Lumberjacks } \\
(\mathrm{N}=226)\end{array}$ & $\begin{array}{c}\text { Referents } \\
(\mathrm{N}=98)\end{array}$ \\
\cline { 2 - 3 } & $<1$ & 1 \\
Restricted flexion & 5 & 4 \\
Restricted extension & 6 & 4 \\
$\begin{array}{l}\text { Restricted lateral } \\
\text { flexion }\end{array}$ & 2 & 2 \\
Restricted rotation & 23 & 15 \\
Tenderness of movement & 23 & \\
\hline
\end{tabular}

Table 8, Results from the manual testing of abdominal and back muscles.

Normal abdominal and

back muscle strength

Weak abdominal and

back muscle strength

Lumberjacks Referents

$(\mathrm{N}=226) \quad(\mathrm{N}=98)$

$(\%)$

$(\%)$

Weak abdominal

muscle strength

Weak back muscle

strength

28

70

32

12

33

13

7 
$(t=1.41) \quad($ table 7$) . \quad H o w e v e r$, soreness during back movement was more common among the former than the latter.

Tenderness in the lumbar spine during palpation was found in 48 lumberjacks and 3 referents, and muscle spasms in 14 lumberjacks and 3 referents. There were no significant differences ( $t=1.46$, palpation; $t=1.21$, spasms) between the two groups.

\section{Muscle testing}

The lumberjacks had significantly weaker abdominal and back muscles than the referents $(p<0.001)$ (table 8$)$. Differences of over $1 \mathrm{~cm}$ in the length of the lower extremities were found in one lumberjack and one referent.

Radiographic examination of the lumbar spine

Because of the standard radiographs some radiographic findings such as tropism were not taken into consideration. The results from the lumbar spine examinations of the lumberjacks and referents are presented in table 9 . The radiographic findings of the referents were normal more often than for the lumberjacks $(\mathrm{p}<$ 0.001). The latter group also had more cases of disc degeneration, traction spur, and Scheuermann and spondylolisthetic changes $(p<0.05)$.

The relationship between certain radiographic findings and anamnestic low-back pain can be seen from table 10 . About one-half of the lumberjacks who had normal radiographic findings had experienced low-back pain, and in one-third of the cases in which disc degeneration was evident there had been no pain. Onefourth of the instances of Scheuermann's disease and over one-third of the cases of spondylolisthesis had no relation to back pain.

About $40 \%$ of the referents who had normal radiographic findings had complained of low-back pain, and two-thirds of those who had disc degeneration had experienced no pain at all.

The relationship between disc degeneration and the length of exposure to felling

Table 9. Number and prevalence (in parentheses) of radiographic findings in the lumber spine.

\begin{tabular}{|c|c|c|c|c|}
\hline \multirow{2}{*}{$\begin{array}{l}\text { Finding } \\
\text { Normal }\end{array}$} & \multicolumn{2}{|c|}{$\begin{array}{l}\text { Lumberjacks } \\
\qquad(\mathrm{N}=224)\end{array}$} & \multicolumn{2}{|c|}{$\begin{array}{l}\text { Referents } \\
(\mathrm{N}=98)\end{array}$} \\
\hline & 42 & $(19 \%)$ & 34 & $(34 \%)$ \\
\hline Spondylar & 30 & & 7 & $\%$ \\
\hline issing $\mathrm{sl}$ & 11 & $(5 \%)$ & 3 & $(3 \%)$ \\
\hline isc deger & 140 & $(62 \%)$ & 50 & $(50 \%)$ \\
\hline First degree & 82 & $(37 \%)$ & 29 & $(29 \%)$ \\
\hline nd degree & 29 & $(13 \%)$ & 16 & $(16 \%)$ \\
\hline Third degree & 18 & $(8 \%)$ & 4 & $(4 \%)$ \\
\hline Fourth degree & 11 & $(5 \%)$ & 1 & \\
\hline $\begin{array}{l}\text { Traction spur or } \\
\text { retrolisthesis }\end{array}$ & 68 & $(30 \%)$ & 19 & $(19 \%)$ \\
\hline n's & & & & \\
\hline Spon & $\begin{array}{l}21 \\
16\end{array}$ & $(7 \%)$ & & $(4 \%)$ \\
\hline $\begin{array}{l}\text { Pseudospondylolis- } \\
\text { thesis }\end{array}$ & 4 & & 1 & 178 \\
\hline $\begin{array}{l}\text { Spondylolysis } \\
\text { Lumbarization or }\end{array}$ & 4 & 1 & - & - \\
\hline sacr & 12 & $(5$ & & \\
\hline Spina bifida occulta & 12 & $(5 \%)$ & & \\
\hline $\begin{array}{l}\text { Block vertebra } \\
\text { Residual changes of }\end{array}$ & 1 & - & & \\
\hline compression fracture & - & 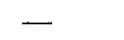 & & $2 \%$ \\
\hline
\end{tabular}

Table 10. Relationship between some radiographic findings to low-back pain.

\begin{tabular}{|c|c|c|c|c|c|c|}
\hline \multirow{2}{*}{ Radiographic finding } & \multicolumn{3}{|c|}{ Lumberjacks } & \multicolumn{3}{|c|}{ Referents } \\
\hline & Pain & & pain & Pain & & Vo pain \\
\hline \multirow{10}{*}{$\begin{array}{l}\text { Normal } \\
\text { Disc degeneration } \\
\text { First degree } \\
\text { Second degree } \\
\text { Third degree } \\
\text { Fourth degree } \\
\text { Scheuermann's disease } \\
\text { Spondylolisthesis } \\
\text { Traction spur or } \\
\text { retrolisthesis }\end{array}$} & 42 & 20 & $(48 \%)$ & 34 & 21 & $(62 \%)$ \\
\hline & 140 & 41 & $(29 \%)$ & 50 & 10 & $(20 \%)$ \\
\hline & 82 & 23 & $(28 \%)$ & 29 & 7 & $(24 \%)$ \\
\hline & 29 & 8 & $(27 \%)$ & 16 & 3 & $(19 \%)$ \\
\hline & 18 & 7 & $(39 \%)$ & 4 & - & - \\
\hline & 11 & 3 & $(27 \%)$ & 1 & - & - \\
\hline & 21 & 5 & $(24 \%)$ & 2 & - & - \\
\hline & 16 & 6 & $(38 \%)$ & 4 & 1 & $(25 \%)$ \\
\hline & & & & & & \\
\hline & 68 & 25 & $(37 \%)$ & 19 & 3 & $(16 \%)$ \\
\hline
\end{tabular}


work that strains the back was evaluated with the aid of a multiple regression analysis (fig 4). The results showed that the length of exposure had no apparent influence on disc degeneration in the lumbar spine when the effect of age was statistically removed.

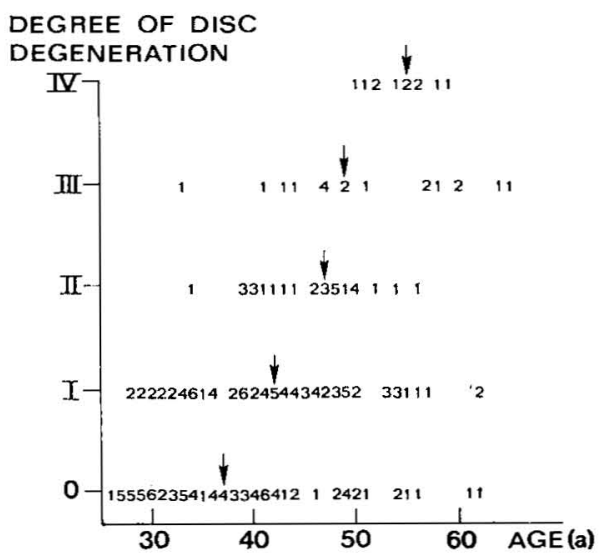

Fig 4. Correlogram between the age of the lumberjacks and the degree of disc degeneration. The figures represent the number of workers. The mean ages in each degeneration category are shown by arrows. $\quad(0=$ no degeneration, I = slight anterior wear and osteophyte formation, II = definite anterior wear and osteophyte formation, III = osteophyte formation and disc narrowing, IV = large osteophytes, marked disc narrowing, sclerosis of vertebral plates, and posterior subluxation)

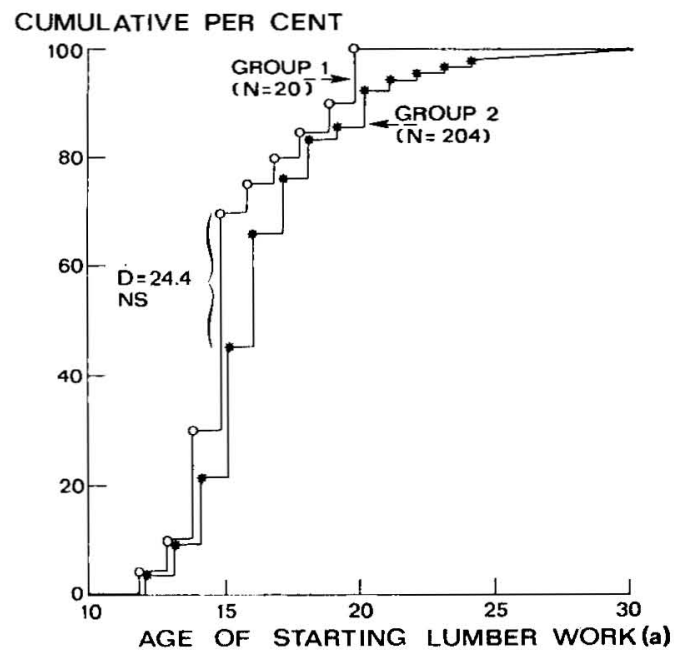

Fig 5. Cumulative histograms of age at the beginning of forest work for the lumberjacks with Scheurermann's changes (group 1) and those without them (group 2). ( $D=$ Kolmogorov-Smirnov difference test statistic)
All three approaches in the statistical analysis of the data yielded (omitting technical details) essentially univocal results. The partial regression/correlation information was consistent with the causal hypothesis that the observed correlation of outcome and exposure was "spurious," ie, it was due to the fact that they were both dependent on age. The Mantel chi-square statistic obtained a diminutive value of $\chi^{2}(1)=0.5$, with a 4- to 6-a age strata $(26-29,30-34, \ldots$, $55-59,60-65$ a), and five outcome and six exposure categories (ranging from 10 to $40 \mathrm{a}$, the midvalues of the intervals being used as scores). In the first analysis of covariance the slopes of the regression lines of the different disc degeneration grade groups ( 0 , I, II, and III, IV having been omitted because of the small group size) between age and length of exposure were parallel. A parallelism was also observable for the slopes of the linear regression lines of the different exposure time groups $(10-14, \ldots 30-40 \mathrm{a}$, the exposure time group of over 34 a serving as the reference category) between age and the outcome variable. The results of the multiple regression analysis are shown in table 11, where it can be seen that the increase in the percentage of explained variance, obtained by the addition of the exposure variable to couple age as regressors, was a negligible $0.2 \%$.

Thus the essential information included in these data is depicted in the correlogram between the age of the lumberjacks and the degree of their disc degeneration (fig 4). The median ages of the subjects in the categories of progressively extended degenerative signs, ie, $37,42,47,49$ and $55 \mathrm{a}$, clearly indicate the effect of customary ageing on disc degeneration.

Fig 5 shows the ages of the subjects at the beginning of forest work and radiographic changes associated with Scheuermann's disease. Those subjects who began forestry work at an early age $(12-15$ a) showed no greater tendency for Scheuermann's disease than those who began at a later age.

The possible effect of age at the beginning of lumber work on the appearance of Scheuermann's changes was studied statistically from cumulative histograms for the two groups of lumberjacks char- 
acterized by the presence (group 1) or absence (group 2) of these signs, as seen in the radiographs. It was discernible that the modes (as well as medians) of the frequency distributions of the compared groups coincided. In addition the mean values were close to each other (group 1: mean $=15.5 \mathrm{a} ; \mathrm{SD}=2.2 \mathrm{a}$; group 2: mean $=16.5 \mathrm{a} ; \mathrm{SD}=3.3 \mathrm{a} ; \mathrm{t}=1.72, \mathrm{NS})$. Since there were some men in group 2 who had started work in the age range of 21 to 30 a (thereby raising the mean value of that group), the result was checked with a nonparametric Kolmogorov-Smirnov test (fig 5). The nonsignificant difference statistic $(\mathrm{D}=24.4)$ safeguarded against postulating for any kind of difference between these two groups with respect to age at beginning of work.

Among the lumberjacks there were seven cases of sacro-illiitis and three cases of osteoarthritis determined radiographically in sacroiliac joints. In addition, one of the lumberjacks had changes of ankylosing spondylitis in the lumbar spine and sacroiliac joints.

\section{Hip and knee joints}

Interview. According to the interview 26 of the lumberjacks had had leg injuries. During the 12 months preceding the investigation four lumberjacks had been absent from work for at least $3 \mathrm{~d}$ because of knee or hip ailments. Only seven of the referents had had leg injuries, and none of them had missed work during the previous 12 months because of knee or hip ailments.

Clinical examination. Three of the lumberjacks walked with a limp. Although all of the lumberjacks were able to squat, three had limited flexion of the hip, and ten had restricted hip rotation. Knee flexion and extension was normal for them all, but eight had slight soreness of movement during flexion and 14 during extension. Six lumberjacks had capsular thickening of the knee.

None of the referents limped. All of them were able to squat and had normal hip and knee movements. Three of the referents showed a slight soreness during knee movement, and two had capsular thickening.

Radiographic examination. Radiographs were taken of the hips and knees of 136 and 224 lumberjacks, respectively. Ninetyeight referents had their knees and hips $\mathrm{X}$-rayed (table 2).

The osteoarthritic changes in the hips and knees of both groups were mild, and there was no significant difference between the lumberjacks and referents with respect to these radiographic findings.

Table 11. Results of a multiple regression analysis, with degree of disc degeneration as the regressand and the length of lumber work and age of the worker as the regressor variables, and the effect of controlling for age.

\begin{tabular}{|c|c|c|c|c|}
\hline Variable & $\begin{array}{l}\text { Regression } \\
\text { coefficient }\end{array}$ & $\begin{array}{l}\text { Standard } \\
\text { error }\end{array}$ & t-test & Beta \\
\hline \multicolumn{5}{|l|}{ First analysis } \\
\hline Age & 0.055 & 0.013 & 4.22 & \multirow{6}{*}{$\begin{array}{l}0.45 \\
0.09\end{array}$} \\
\hline Exposure & 0.012 & 0.015 & 0.81 & \\
\hline Constant & 1.529 & 0.347 & -4.40 & \\
\hline $\begin{array}{l}\text { Variance of regressand }=1.275 \\
\text { Residual variance }=0.937\end{array}$ & & & $\begin{array}{l}\mathrm{DF}=222 \\
\mathrm{DF}=220\end{array}$ & \\
\hline Multiple correlation & & & & \\
\hline squared $R^{2}=27.2 \%$ & & & $F=41.1$ & \\
\hline \multicolumn{5}{|l|}{ Second analysis } \\
\hline $\begin{array}{l}\text { Age } \\
\text { Constant }\end{array}$ & $\begin{array}{r}0.064 \\
-1.660\end{array}$ & $\begin{array}{l}0.007 \\
0.308\end{array}$ & $\begin{array}{r}9.03 \\
-5.38\end{array}$ & \multirow[t]{4}{*}{0.52} \\
\hline Variance of regressand $=1.275$ & & & $\mathrm{DF}=222$ & \\
\hline Residual variance $=0.930$ & & & $\mathrm{DF}=221$ & \\
\hline $\begin{array}{l}\text { Multiple correlation } \\
\text { squared } \mathrm{R}^{2}=27.6 \%\end{array}$ & & & $F=81.6$ & \\
\hline
\end{tabular}


Table 12. Radiographic findings in knee and hip joints.

\begin{tabular}{|c|c|c|}
\hline Finding & Lumberjacks & Referents \\
\hline Knee & $(N=224)$ & $(\mathrm{N}=98)$ \\
\hline $\begin{array}{l}\text { Osteoarthritis } \\
\text { Chondromatosis } \\
\text { Mus articulare } \\
\text { Traumatic changes }\end{array}$ & $\begin{array}{l}6 \\
- \\
-\end{array}$ & $\begin{array}{ll}3 & (3 \%) \\
1 & (1 \%) \\
1 & (1 \%) \\
3 & (3 \%)\end{array}$ \\
\hline Hip & $(N=116)$ & $(\mathrm{N}=98)$ \\
\hline $\begin{array}{l}\text { Osteoarthritis } \\
\text { Legg-Perthes-Calvé } \\
\text { disease } \\
\text { Dysplasia coxae }\end{array}$ & $\begin{array}{l}7(5 \%) \\
- \\
-\end{array}$ & $\begin{array}{ll}7 & (7 \%) \\
2 & (2 \%) \\
1 & (1 \%)\end{array}$ \\
\hline
\end{tabular}

\section{Discussion}

Since 1972 the company for which the lumberjacks in this study worked has conducted preemployment medical examinations. The percentage of rejections based on these examinations has been less than $1 \%$. The subjects come from localities that do not usually provide many other possibilities for employment besides forestry. All things considered, the influence of relatively long hard work on the low back and the joints of the lower extremities should presumably show up quite clearly. There is also a clear difference between the strenuousness of the work of the two groups.

Back ailments are known to be common among all work groups. In accordance there was no significant difference in the occurrence of low-back pain between the lumberjacks and the referents. Sixty-two percent of the lumberjacks had low-back ailments, and this percentage is approximately the same as that established for a similar group in Sweden (21). It is probable that trauma is the cause of many etiologically unclear back ailments $(5,15)$. Especially among lumberjacks, because of the type of work, unknown trauma etiology may play a role in the appearance of lowback pain, which itself may be related to disturbances in ligament and muscle structure in particular.

In this study it was expected that, because of the types of work involved, the seriousness of subjective back pain would be greater among the lumberjacks than the referents. This situation was not how- ever the case. One possible explanation is that the work motivation of the lumberjacks was better than the that of the referents. According to one study (14) highly mechanized work and a less degree of influence on work output negatively affect a worker's satisfaction, health and, in turn, his subjective feelings of health. In this respect piecework, especially in lumbering, may be considered a better alternative than a straight hourly wage.

There was relatively little absence from work because of low-back pain among the lumberjacks of the present study. This finding was due in part at least to the piecework wage system, which discourages absences from work for minor problems. One Swedish study (28) also made similar observations. In general, the less interesting work is and the more regulated it is by a schedule and supervision, the more common absenteeism from work appears to be (47). On the other hand, especially for lowback pain, it is difficult to determine if the absence is due to somatic, psychological, or social reasons. Low-back pain is a symptom, not a disease, and the reason for it is often something other than the back (34).

It is worth considering the fact that many of the lumberjacks in this study began forest work at the ages of $12-15$ a, serving as helpers for their fathers in the collection and transportion of logs. Nevertheless, the average age of the onset of back pain in these men was no different from that of the referents.

Changes in posture and tenderness of movement were more common among the lumberjacks than the referents.

It has been found that regular exercise appears to prevent back pain (24), and in this study only one-fifth of the lumberjacks exercised regularly, while one-half of the referents did.

The strength of the back and abdominal muscles of the subjects was, on the average, weaker than that of the referents. Similar findings have been obtained in other studies dealing with lumberjacks and reinforced concrete workers $(26,44)$. There are, however, differences of opinion as to the significance of the strength of these muscles in regard to low-back pain $(8,11,20,41,46,49,55)$. Nevertheless it appears that the strength of these muscles 
does have some importance to low-back pain $(13,70)$.

The determination of relationships between individual radiographic findings and low-back pain is difficult. An individual often has several radiographic findings, and some may be overlooked, eg, slight disc degeneration. Still, certain facts may be determined. Among the lumberjacks the correlation between radiographic findings and low-back pain varied extremely. For example, half of the lumberjacks with a radiographically normal lumbar spine had experienced lowback pain. This result points to nonspinal injuries. In many of the cases of disc degeneration, spondylolisthesis and Scheuermann's disease, no low-back pain had been indicated. Even in some serious cases of disc degeneration, there had been no low-back pain. This absence of pain may mean the change was "mute," as has been shown to occur sometimes $(22,69)$.

Certain radiographic findings such as multiple disc degeneration, spondylolisthesis, and Scheuermann's disease seem to have prognostic value in relation to lowback pain $(35,36,42,62,63)$, even though their importance was very limited in our study. Because the results of clinical examinations in cases of low-back pain are often negative, radiographic findings are often cited as the cause of low-back pain, even if the connection seems questionable. Especially in preemployment examinations radiographic findings are considered valuable to the prognosis of lowback pain and the determination of work ability (48). According to many investigations $(9,30,54,61)$ the tendency towards low-back ailments cannot be predicted on the basis of radiographs of the lumbar spine, especially in the context of routine investigations.

In attempts to determine the relationship between heavy work and low-back pain, attention has been especially drawn to disc degeneration. This change may lead to disc prolapse or segmental instability, which is often blamed for low-back pain $(33,38)$.

Many studies $(1,25,31,57)$ have concluded that heavy physical work hastens the manifestation of disc degeneration. The contrary opinion also exists however $(7,20,22)$. In this study the difference between the lumberjacks and the referents was relatively small with respect to the occurrence of disc degeneration. The prevalence of intervertebral disc degeneration in one English study was $65 \%$ for males over 35 a of age, a result higher than that of the present study and another Finnish study as well (67). With the age factor removed there appeared to be no correlation between the length of heavy work and disc degeneration among the lumberjacks of this study.

In the study of the development of disc degeneration, age and mechanical stress, as well as other factors, must be taken into consideration. Hereditary factors may play an important role in the development of disc degeneration (40). Recent studies $(2,16)$ indicate that also the mechanism of autoimmunization can play a part in these changes. Because of these varied factors, however, it is difficult to assess the role that heavy work has in causing these changes.

In the present study, as in one Swedish study (21), both the group under study and its referents, in comparison to each other, had relatively few radiographic findings in the hip or knee joints. The same observation has been made of professional soccer players and long distance runners $(4,45,51)$. On the other hand the occurrence of osteoarthritis in the knees of reinforced concrete workers was relatively high $(38 \%)(67)$.

In experimental animals it has been proved that sustained joint immobilization and compression can advance osteoarthritis $(29,56)$. Already long ago it was shown that joint damage has no relation to heavy lifting or extensive walking (19, 31). Neverthless, in work life, heavy work has been considered the major cause of osteoarthritis. On the whole, however, osteoarthritis is admitted to have a multifactorial etiology $(39,60)$.

Although osteoarthritic changes increase with age, pathological findings do not support ageing as a cause of osteoarthritis (60). Studies with test animals $(17,39)$ have shown that osteoarthritis begins with biochemical changes in the cartilage, and the actual degenerative changes manifest themselves much later. In particular osteoarthritis is accompanied by an inflammatory component $(23,50,60)$. Though 
mechanical factors seem to be important in the etiology of osteoarthritis (52), this affliction cannot be explained only on the basis of wear and tear. It seems that heavy lumbering work in general, when carried out in an ergonomically correct way, is not a significant factor in the development of osteoarthritis in the hip and knee joints.

\section{Conclusions}

There was no clear difference between the lumberjacks and the referents in regard to the occurrence of low-back pain. Among the lumberjacks low-back pain started after an average of 12 a of work.

The lumberjacks had more scoliosis, tenderness of movement in the back, and subjective low-back pain than the referents. There was no distinct difference between the groups as to palpation tenderness and muscle spasm in the back.

The results of the manual testing of the back and abdominal muscles showed that the lumberjacks had weaker muscle strength than the referents.

Among the lumberjacks trauma seems to be important to the etiology of low-back pain.

The lumberjacks had more disc degeneration and traction spur changes than the referents. There was no statistical correlation between the length of forest work of the lumberjacks and the occurrence or degree of disc degeneration.

In many cases there was no correlation between low-back pain and radiographic findings. About half of the cases having normal radiographic findings had had low-back pain. Of those lumberjacks who had had disc degeneration, Scheuermann's disease, or spondylolisthesis only, a portion had had low-back pain (two-thirds, threefourths and two-thirds, respectively). The significance of a routine radiographic examination as a part of a preemployment health examination is very limited in regard to the prognosis of low-back pain.

Osteoarthritic changes in hip and knee joints were slight in both groups. Felling work did not seem to increase the number of these changes in these joints. It is evident that felling work in an ergonomically correct manner does not cause lowback pain, except in cases of trauma, any more than other types of work do. Nevertheless, because of the demands made on the back by felling work, low-back pain is frequently a hindrance to the performance of such work, particularly for older workers.

In consideration of the fact that the present study included many subjects who had done felling work for a rather long time and at the same time had not suffered from low-back pain, it seems probable that consitutional factors are also important to the etiology of low-back pain.

\section{Acknowledgments}

We would like to express our appreciation to the Metsämiesten Säätiö, Helsinki, for its financial support.

We would also like to thank Ms $\mathrm{K}-\mathrm{L}$ Laine for her technical aid and M Nurminen, LSc, for his statistical handling of the data. In addition we are grateful to EnsoGutzeit Ltd, especially to its Forest Division, for the help we received.

\section{References}

1. Billenkamp G. Körperliche Belastung und Spondylosis deformans. Fortschr Geb Röngenstr 116 (1972) 211-216.

2. Bislo R, Marachisello P, Lockshin IM, Hart D, Marcus R, Grande J. Autoimmunological basis of disc degeneration. Clin ortop 121 (1976) 205-211.

3. Bond M. Low back x-rays: Criteria for their use in placement examinations in industry. J occup med 6 (1964) $378-380$.

4. Brodelius A. Osteoarthritis of the talar joints in footballers and ballet dancers. Acta orthop scand 30 (1960) 309-314.

5. Brown J. Lifting as an industrial hazard. Am ind hyg assoc j 34 (1973): 7, 292-297.

6. Cailliet R. Low back pain syndrome. F.A. Davis Company, Philadelphia, PA 1968.

7. Caplan P, Freedman L, Connelly T. Degenerative joint disease of the lumbar spine in coalminers. A clinical and x-ray study. Arthritis rheum 9 (1966) 693-702.

8. Chaffin D, Herring $G$. The effectiveness of preemployment strength testing for manual materials handling jobs. In: Proceedings from 6 th congress of the international ergonomic association, 11-16 July 1976. University of Maryland, College Park Campus, MD 1976, pp 17-23.

9. Chaffin D, Park K. A longitudinal study of low back pain as associated with occupational weight lifting factors. Am ind hyg assoc j 34 (1973): 12, 513-525.

10. Cohen J, Cohen P. Applied multiple re- 
gression/correlation analysis for the behavioral sciences. John Wiley \& Sons, New York, NY 1965.

11. Dalen A. Olika ryggåkommor och deras frekvens hos värnpliktiga under grundutbildningen vid 13. Försvarsmedicin 10 (1974): suppl 1, 13-16.

12. Daniels $\mathrm{L}$, Williams $\mathrm{M}$, Worthingham $\mathrm{C}$. Muscle testing: Techniques of manual examination. Third edition. WB Saunders Company, London 1972, pp 20-30.

13. Farfan $H$. Muscular mechanism of the Iumbar spine and the position of power and efficiency. Orthop clin north am 6 (1975) 135-144.

14. Frankenhaeuser M, Gardell B. Underload and overload in working life: Outline of a multidisciplinary approach. $\mathrm{J}$ hum stress 2 (1976) 35-43.

15. Frymore J, Pope M. The role of trauma in low back pain: A review. Trauma 18 (1978) 628-634.

16. Gertzbein S. Degenerative disc disease of the lumbar spine: Immunological implications. Clin ortop 129 (1977) 68-71.

17. Glynn L. Primary lesion in osteoarthrosis. Lancet 2 (1977) $574-575$.

18. Heikinheimo L, Heikinheimo $M$, Lehtinen M, Reunala A. Suomalainen metsätyömies. Werner Söderström Oy, Porvoo 1972, $35-57$.

19. Heine J. Uber die Arthritis deformans. Wirchows arch path anat 260 (1926) 521663.

20. Hirsch C. Etiology and pathogenesis of Iow back pain. Isr $\mathrm{j}$ med sci 2 (1966) 362-369.

21. Hult $\mathrm{L}$. The Munkfors investigation. Acta orthop scand (1954): suppl 16, $76 \mathrm{p}$.

22. Hult L. Cervical, dorsal and lumbar spine syndromes. Acta orthop scand (1954): suppl 17, $102 \mathrm{p}$.

23. Huskisson E, Dieppe $\mathrm{P}$, Tucker A, Cannel L. Another look at osteoarthritis. Ann rheum dis 38 (1979) 423-426.

24. Karvonen M, Järvinen T, Nummi J. Säännöllinen voimistelu ehkäisee selkävaivoja. Työ Terveys Turvallisuus (1975): 9, 46-48.

25. Kellgren $J$, Lawrence $J$. Rheumatism in miners: Part II. X-ray study. $\mathrm{Br} \mathrm{j}$ ind med 9 (1952) 197-207.

26. Korhonen $\mathrm{O}$, Nummi J, Nurminen $\mathrm{M}, \mathrm{Ny}-$ gård $\mathbf{K}$, Soininen $\mathrm{H}$, Viikeri M. Metsätyöntekijä: II. Terveys verrattuna ammatissa toimivan väestön terveyteen [Finnish lumberjacks II: Their health in comparison to that of another employed population]. Institute of Occupational Health, Helsinki 1977. (Työterveyslaitoksen tutkimuksia no 126).

27. Koskela A, Nummi $P$, Järvinen $T$, Pesonen $K$. IBM:n konttorikone- ja tietokonemekaanikkojen terveystarkastus. In: Nummi J, Järvinen $T$, ed. Kipuselkä ja sen hoito. Institute of Occupational Health, Helsinki 1974, pp 149-160. (Työterveyslaitoksen julkaisuja 33).

28. Kylin B, Gerhardsson G, Hansson J-E, Lindström J-M, Liljeberg $\mathrm{B}$, Svensson $\AA$, Åstrand J. Hälso- och miljöundersökning bland skogsarbetare. Arbetsmedicinska
Institutet, Stockholm 1968. 117 p. (AI rapport $\mathrm{nr}$ 5).

29. Langenskiöld A, Michelsson J-E, Videman $T$. Osteoarthritis of the knee in rabbit produced by immobilization. Acta orthop scand 50 (1979) 1-14.

30. La Rocca H, Macnab I. Value of preemployment radiographic assessment of the lumbar spine. Can med assoc j 101 (1969) $49-54$.

31. Lawrence J. Rheumatism in coal miners: Part III. Occupational factors. $\mathrm{Br} \mathrm{j}$ ind med 12 (1955) 249-261.

32. Lawrence J. Disc regeneration: Its frequency and relationship to symptoms. Ann rheum dis 28 (1969) 121-138.

33. MacNab I. The traction spur. $J$ bone $j t$ surg am vol 53 (1971) 663-670.

34. MacNab I. Backache The Williams \& Wilkins Company, Baltimore, MD 1977.

35. Magora A, Schwartz A. Relation between the low back pain syndrome and $x$-ray findings: I. Degenerative osteoarthrosis. Scand j rehabil med 8 (1976) 115-125.

36. Magora A, Schwartz A. Relation between the low back pain syndrome and $x$-ray findings: Transitional vertebra (mainly sacralization). Scand $j$ rehabil med 10 (1978) 135-145

37. Mantel N. Chi-square tests with one degree of freedom; extensions of the MantelHaenszel procedure. $\mathrm{J}$ am stat assoc 58 (1963) 690-700.

38. Morgan F, King T. Primary instability of lumbar vertebral as a common cause of low back pain. $J$ bone jt surg br vol 39 (1957) 6-22.

39. Muir H. Molecular approach to the understanding of osteoarthrosis. Ann rheum dis 36 (1977) $199-208$.

40. Muller W. Pathophysiologie der Arthrosen. Ther Umsch 35 (1978) 147-154.

41. Nachemson A, Lindh M. Measurement of abdominal and back muscle strength with and without low back pain symptoms. Scand j rehabil med 1 (1969) $60-65$.

42. Nachemson A, Lindh $M$. The lumbar symptoms: An orthopaedic challence. Spine 1 (1976) 59-66.

43. Nachemson A, Lindh M. Study into causes and treatment of low back pain held neglected. Rheumatol news int 7 (1979) 8.

44. Nummi J, Järvinen $T$, Stambej U, Wickström G. Diminished dynamic performance capacity of back and abdominal muscles in concrete reinforcement workers. Scand $j$ work environ health 4 (1978): suppl 1, $39-46$.

45. Oka M, Hatanpää S. Degenerative hip disease in adolescent athletes. Med sci sports 8 (1976) $77-80$.

46. Onishi N, Nomina $H$. Low back pain in relation to physical work capacity and local tenderness. J hum ergology 2 (1973) $119-132$

47. Parvi V. Työolot ja tilapäinen työkyvyttömyys. In: Meteli, ed. Occupational position, working conditions and morbidity among employees of machine industry. Research Institute of Physical Culture and 
Health, Jyväskylä 1977, pp 87-92. (Research institute of physical culture and health publications no 18).

48. Parvi V, Virolainen M. Roentgenographic findings of the lumbosacral spine in preemployment examinations of lumbermen with special reference to spondylolisthesis. Scand $j$ work environ health 1 (1975) $40-44$.

49. Pedersen O, Petersen R, Stafbeldt E. Back pain and isometric back muscle strength of workers in a Danish factory. Scand $j$ rehabil med 7 (1975) 125-128.

50. Peltonen L. Enzymes and articular destruction in rheumatoid arthritis and osteoarthrosis. Acta univ ouluensis D 25 (1978) $32 \mathrm{p}$.

51. Puranen J, Ala-Ketola L, Peltokallio P, Saarela J. Running and primary osteoarthritis of the hip. $\mathrm{Br}$ med $\mathrm{j} 1$ (1975) $424-425$.

52. Radin E. Mechanical aspects of osteoarthritis. Bull rheum dis 26 (1976) 862865.

53. Raitasalo R. Työkyvyttömyyseläkkeelle johtaneen sairastavuuden kasvusta ja sen syistä. In: Valtion lääketieteellinen toimikunta, ed. Tuki- ja likuntaelinten tautien tutkimus seminaari, Espoo 14.10.1977. Academy of Finland, Helsinki 1977, pp. 12-19. (Publications 15).

54. Redfield J. The low back x-ray as a preemployment screening tool in the forest products industry. J occup med 13 (1971) $219-225$.

55. Rowe M. Preliminary statistical study of low back pain. J occup med 5 (1963) 336341.

56. Salter R, Field P. The effect of continuous compression on living articular cartilage. J bone jt surg am vol 42 (1960) $31-49$.

57. Schmorl G, Junghanns $H$. The human spine in health and disease. Second Am ed. Grune and Stratton, New York, NY 1971.

58. Schober P. The lumbar vertebral column and backache. Münch med Wochenschr 84 (1937) $336-343$.

59. Sievers K. Tuki- ja liikuntaelinten tau- tien sairastavuus ja sen mittaamisen ongelmia. In: Valtion lääketieteellinen toimikunta, ed. Tuki- ja liikuntaelinten tautien tutkimus seminaari, Espoo 14.10. 1977. Academy of Finland, Helsinki 1977 , pp 7-11. (Publication 15).

60. Sokoloff L. The biology of degenerative joint disease. University of Chicago Press, Chicago, IL 1969.

61. Splithoff C. Lumbosacral junction: Roentgenographic comparison of patients with and without backache. $\mathrm{J}$ am med assoc 152 (1953) 1610-1615.

62. Torgerson W, Dotter W. Comparative roentgenographic study of the asymptomatic lumbar spine. $J$ bone jt surg am vol 58 (1976) 850-863.

63. Stoddard A, Osborn J. Scheuermann's disease or spinal osteochondrosis. Its frequency and relationships with spondylosis. J bone jt surg br vol 61 (1979) 56-62.

64. Troup J. Relation of lumbar spine disorders to heavy manual work and lifting. Lancet 1 (1965) 857-861.

65. Westrin C-G. Low back sick listing. A nosological and medical insurance investigation. Scand j soc med (1973): suppl 7, $127-134$.

66. Wickström $\mathrm{G}$, Hänninen $\mathrm{K}$, Lehtinen $\mathrm{M}$, Riihimäki $H$. Previous back syndromes and present back symptoms in concrete reinforcement workers. Scand $j$ work environ health 4 (1978): suppl 1, 20-28.

67. Viikeri M, Nummi J, Riihimäki V, Wickström G. Radiologically detectable Iumbar disc degeneration in concrete reinforcement workers. Scand $j$ work environ health 4 (1978): suppl 1, 47-53.

68. Viitasalo J, Viljamaa K, Komi P. Dynamometers for measurements of isometric trunk and leg forces. Jyväskylä University, Jyväskylä 1976. 20 p. (Research reports from the department of biology of physical activity no 22)

69. Wiltse L. The effect of the common anomalies of the lumbar spine upon disc degeneration and low back pain. Orthop clin north am 2 (1971) 569-582.

70. Wood P. Applied anatomy and physiology of the vertebrae. Physiotherapy 65 (1979) $248-249$.

Received for publication: 10 July 1980 